\title{
Influence of Polypropylene and Steel Fibers on the Performance and Crack Repair of Self-Compacting Concrete
}

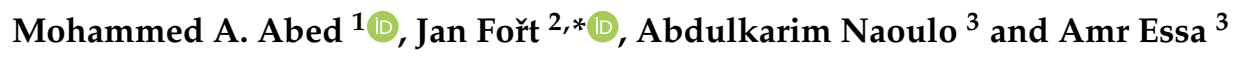 \\ 1 Department of Civil and Environmental Engineering, Rutgers, The State University of New Jersey, \\ Piscataway, NJ 08854, USA; mohammed.abed@rutgers.edu \\ 2 Department of Materials Engineering and Chemistry, Faculty of Civil Engineering, Czech Technical \\ University in Prague, 16629 Prague, Czech Republic \\ 3 Department of Structural Engineering, Budapest University of Technology and Economics, \\ 1111 Budapest, Hungary; abdulkarim-naoulo@live.com (A.N.); amr9993essa@gmail.com (A.E.) \\ * Correspondence: jan.fort@fsv.cvut.cz
}

Citation: Abed, M.A.; Fořt, J.;

Naoulo, A.; Essa, A. Influence of Polypropylene and Steel Fibers on the Performance and Crack Repair of Self-Compacting Concrete. Materials 2021, 14, 5506. https://doi.org/ $10.3390 / \mathrm{ma} 14195506$

Academic Editor: Dario De Domenico

Received: 9 September 2021

Accepted: 20 September 2021

Published: 24 September 2021

Publisher's Note: MDPI stays neutral with regard to jurisdictional claims in published maps and institutional affiliations.

Copyright: (C) 2021 by the authors. Licensee MDPI, Basel, Switzerland. This article is an open access article distributed under the terms and conditions of the Creative Commons Attribution (CC BY) license (https:// creativecommons.org/licenses/by/ $4.0 /)$.

\begin{abstract}
The research reported in this paper aims to evaluate the epoxy injection technique used to strengthen fiber-reinforced self-compacting concrete (FRSCC) with high strength. This method is carried out on ruptured concrete specimens to assess the efficiency of the epoxy resin adhesive injection retrofitting technique for strength and stiffness. Five FRSCC mixes were designed and placed using different types (steel and polypropylene) and contents $(0 \%, 0.25 \%$, and $0.45 \%$ by volume) of fibers. The fresh and mechanical properties in addition to the microstructure of produced mixes were evaluated to assess the impact of fibers on the behavior of FRSCC. Results showed that the workability of FRSCC is reduced by increasing steel or polypropylene fiber content; however, the rheological characteristics of placed mixes satisfied the European Guidelines for Self-Compacting Concrete recommendation for fresh concrete. Also, splitting tensile, flexural, and shear strengths were enhanced by increasing fiber content. The simultaneous application of epoxy injection in FRSCC for repairing damaged concrete beams was shown to be highly effective.
\end{abstract}

Keywords: epoxy injection; polypropylene fiber; steel fiber; mechanical properties; crack repair; workability

\section{Introduction}

The versatility and efficiency of concrete as a construction material have demonstrated its ability to become the ultimate building material in the world. Despite concrete's compression capacity, the low tensile strength and brittle characteristics of concrete have necessitated overcoming this weakness by using several types of reinforcement (steel, fiber-reinforced polymer, fibers, etc.). Consequently, enhanced concrete service life and durability can be attained by overcoming cracks issues [1]. The influence of fibers on the workability of self-compacting concrete (SCC) requires attention during the placement of structural concrete elements. Research has proven that using randomly distributed fibers can alter the fresh and mechanical properties of concrete [2,3]. Depending on the shape and type of fibers, overcoming cracks and brittleness can be successfully achieved in cement-based materials. For the past few decades, extensive experimental work has been conducted on a wide variety of fibers including natural, synthetic, and metallic fibers, for which recommendations and guidelines have been proposed for engineering applications.

The utilization of steel fibers in concrete has been highly investigated in the past two decades, and the experimental results have proved its capacity for structural concrete applications. da Silva et al. [4] pointed out that the use of steel fibers enhances the flexural toughness and flexural strength of SCC. Other studies on the addition of steel fibers into concrete confirmed that the splitting tensile strength and modulus of rupture are enhanced as well [5]. Design codes including ACI 318 [6] and fib [7] have endorsed fibers to be used 
for shear reinforcement. To evaluate the shear strength of fiber-reinforced concrete elements, two different formulations are provided by the Model code. Similarly, the American code permits $0.75 \%$ as a minimum shear reinforcement of steel fibers to be used in volume fractions in normal-strength concrete beams. However, Khalo et al. [8] highlighted the negative impact of using steel fibers on the slump-flow and V-funnel times of produced (SCC) concerning volumetric content. Likewise, the corresponding compressive strength of produced SCC has decreased with attribution to workability [9]. Other issues have been reported on the use of steel fibers in concrete, including corrosion and high volumetric density, which create limitations on its use [10,11].

Considering the disadvantages of the incorporation of steel fibers in concrete, polymerbased fibers (polypropylene fibers) are considered a good alternative. Owing to their good chemical stability and hydrophobic nature, and long-term durability, performance in harsh environments can be attained [12,13]. Additionally, the use of polypropylene fibers has proven its ability to reduce the sensitivity of concrete to cracking due to shrinkage. Sun and $\mathrm{Xu}$ [14] reported that the use of polypropylene fibers up to $0.15 \%$ did not affect the compressive strength results of conventional concrete. Similar results were obtained for high-strength concrete with polypropylene fibers up to $0.45 \%$ volume fraction [15]. Multiple studies have been carried out to reveal the most practical way of utilizing polypropylene fibers on the mechanical concrete properties while controlling their negative impact on concrete fresh characteristics. Fiber-reinforced self-compacting concrete (FRSCC) having $0.5 \%$ fiber volume showed an adequate filling capacity [16]. To control the drop in FRSCC workability, Khayat et al. [17] suggested maintaining a constant mortar thickness over coarse aggregate and fiber inclusions. The corresponding experimental results showed that $0.75 \%$ is the critical polypropylene volume dosage and that $0.5 \%$ is the proper dosage for steel fibers. If a higher fiber dosage is needed, a viscosity-modifying agent can be used to overcome blockage and segregation of FRSCC.

Different cementitious and polymer materials are used for crack repair in reinforced concrete structures. Epoxy injection is considered an effective repair method. Based on the ACI 546 [18] "ACI Concrete Repair Guide", epoxy resin is considered the most commonly used repair material for cracks since it possesses very good bonding and durability characteristics. According to Issa and Debs [19], if repair is required to restore the structural integrity of a crack, it should be repaired with epoxy either by injection (epoxy injection method) or by gravity flow (gravity filling method). Cracked cubes injected with epoxy showed an increase in tensile and compressive strength across the crack (around 11\% reduction in the compressive strength of epoxy injected cubes, as compared to control ones with a $40 \%$ decrease) if further cracking is not anticipated. Another study conducted by Ekenel and Myers [20] has shown the impact of environmental conditioning on crack injection using carbon fiber-reinforced polymer strengthening. Results have proven an increase in stiffness in the linear region of load-displacement curves for all reinforced concrete beams injected with epoxy (the increase was noticed to be 3.5 times than control specimens).

French et al. [21] approved the efficiency of using epoxy to restore damaged specimens (over $85 \%$ of the energy dissipation characteristics, stiffness, and strength of the original specimens are restored). Nikoupour and Nehdi studied the behavior of reinforced concrete beams after applying a low viscosity epoxy injection for repair. The study revealed an enhancement of stiffness in the linear region of the load-displacement curves of all the repaired reinforced concrete beams [22]. Ahmad et al. [23] reported in their study that the use of the epoxy injection technique to repair cracks in simply supported beams provided a considerable enhancement in the load-carrying capacity of the beams after repair (considerable $49 \%$ increase in the load-carrying capacity). On the other hand, this approach requires further verification to validate the accuracy and effectiveness [24].

The abovementioned literature review reveals that the majority of published papers on the incorporation of fibers in concrete have been restricted to the addition of fibers only; however, limited investigations have assessed the impact of epoxy injections on 
the flexural strengthening of FRSCC. In this regard, FRSCC mixtures modified by steel and polypropylene fibers were designed and subjected to flexural strength tests to form cracks. Consequently, the coupled effect of fibers and epoxy injection postrepairing phase to enhance the properties of FRSCC was investigated to widen the information about this type of concrete to practically apply it in the construction industry. Obtained results reveal benefits associated with the epoxy treatment of formed cracks in terms of enhancement of mechanical strength.

\section{Methods}

\subsection{Materials}

Cement, sand, coarse aggregate, water, superplasticizer, and fibers have been used to produce the FRSCC with high strength. Thus, a low w/c ratio (0.35) and high powder content $\left(500 \mathrm{Kg} / \mathrm{m}^{3}\right)$ were intended for casting SCC to ensure adequate rheological properties. Ordinary Portland Cement (OPC) CEM I 42.5 N complying with the European standard [25] was used. Table 1 shows the chemical and physical characteristics of the cement.

Table 1. Chemical compositions and physical properties of cement.

\begin{tabular}{cc}
\hline Measured Property & CEM I \\
\hline Density $\left(\mathrm{g} / \mathrm{cm}^{3}\right)$ & 3.02 \\
Specific surface area $\left(\mathrm{cm}^{2} / \mathrm{g}\right)$ & 3326 \\
Loss on ignition & 3.0 \\
$\mathrm{SiO}_{2}$ & 19.33 \\
$\mathrm{CaO}$ & 63.43 \\
$\mathrm{MgO}$ & 1.45 \\
$\mathrm{Fe}_{2} \mathrm{O}_{3}$ & 3.42 \\
$\mathrm{Al}_{2} \mathrm{O}_{3}$ & 4.67 \\
$\mathrm{SO}_{3}$ & 2.6 \\
$\mathrm{Chloride} \mathrm{content} \mathrm{Free} \mathrm{CaO}_{\mathrm{K}_{2} \mathrm{O}}$ & 0.04 \\
$\mathrm{Na}_{2} \mathrm{O}$ & 0.71 \\
& 0.78 \\
\end{tabular}

Local natural quartz river (Danube river) fine and coarse aggregates were used by $45 \%$ and $55 \%$ proportions, respectively. Figure 1 shows the sieve analysis of the used aggregates. The nominal aggregate size is $16 \mathrm{~mm}$; it has a serious impact on strength in the case of high-strength concrete, and it has a positive impact on fatigue performance when the fiber is used.

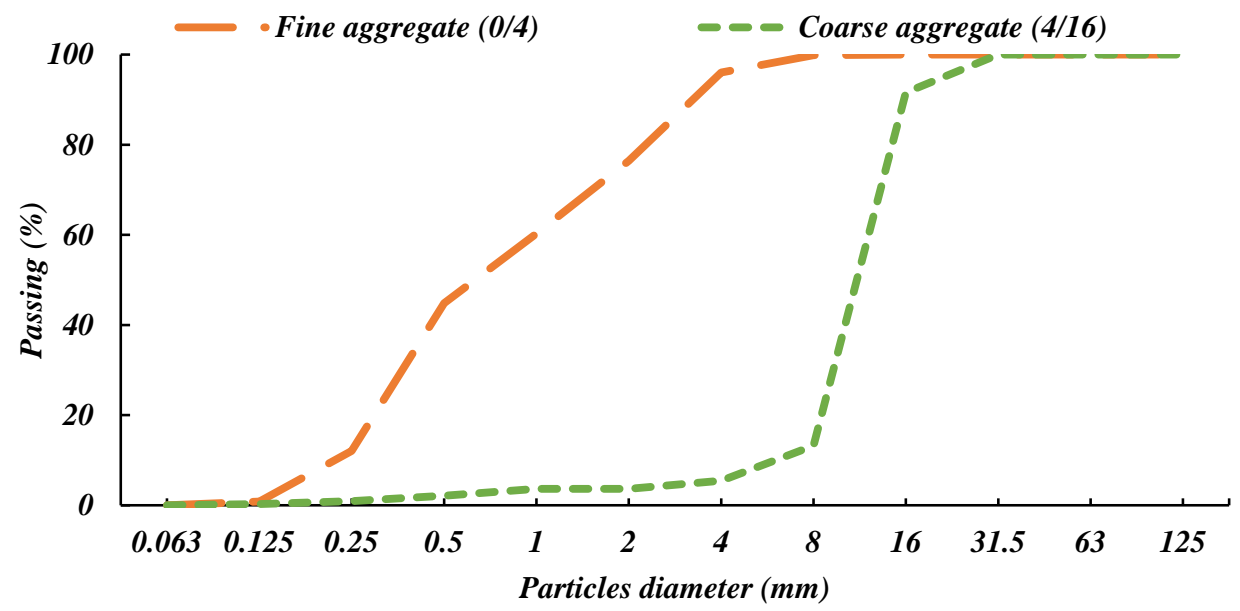

Figure 1. Grading curves of sand, quartz coarse aggregate, and expanded clay LWA. 
A modified polycarboxylates aqueous solution superplasticizer (Sika ViscoCrete-5 $\mathrm{Neu}$ ) was used to achieve the required strength and workability under the European Guidelines for SCC [26].

It is important to note that the superplasticizer was added at the same amount for all mixes to assess the effect of steel and synthetic fibers on the fresh properties of SCC; however, this amount was optimized initially for the control mix. Two types of fibers were used in the present work: steel and synthetic fibers. The steel fiber was a 3D 65/60 BG Dramix, which is known for its advantages such as 3D, combining high performance, durability, and ease of use, and it is a time-saving and cost-efficient solution [27]. The synthetic fiber was polypropylene fiber; its type is Concrix, which is a unique bicomponent polymer fiber with a structured surface. Its high modulus of elasticity guarantees higher strength, where its special structured shell ensures excellent bonding to the concrete.

It is known for its advantages, such as high tensile strength and excellent postcrack behavior, in addition to its high resistance to aggressive fluids and corrosion and that provides a longer service life with minimal maintenance requirements. In addition, it can be handled easily because of its low weight. Table 2 shows the properties of both steel and synthetic fibers used, while Figure 2 presents their shape. Cracked surfaces in damaged specimens were sealed using a two-component epoxy. The specifications of the used epoxy were $30 \mathrm{MPa}$ for tensile strength, $0.5 \%$ strain, 98 compressive strength $\mathrm{MPa}$, and $15.9 \mathrm{MPa}$ for the bond strength.

Table 2. The main properties of the used Steel and Synthetic (polypropylene) fibers.

\begin{tabular}{ccc}
\hline Type & $\begin{array}{c}\text { Steel Fiber } \\
\text { 3D 65/60 BG } \\
\text { Dramix }\end{array}$ & $\begin{array}{c}\text { Synthetic Fiber } \\
\text { Macro Fiber } \\
\text { Concrix }\end{array}$ \\
\hline Material & Steel & Polyolefin \\
Density $\left(\mathrm{g} / \mathrm{cm}^{2}\right)$ & 7.85 & 0.91 \\
Length $(\mathrm{mm})$ & $60 \mathrm{~mm}$ & $50 \mathrm{~mm}$ \\
Diameter $(\mu \mathrm{m})$ & $900 \mu \mathrm{m}$ & $500 \mu \mathrm{m}$ \\
Colour & gray & yellow \\
Number of fibers by kg & 3200 & 150,000 \\
Tensile strength $(\mathrm{MPa})$ & 1160 & 590 \\
Modulus of elasticity $(\mathrm{GPa})$ & $>210$ & $>11$ \\
\hline
\end{tabular}
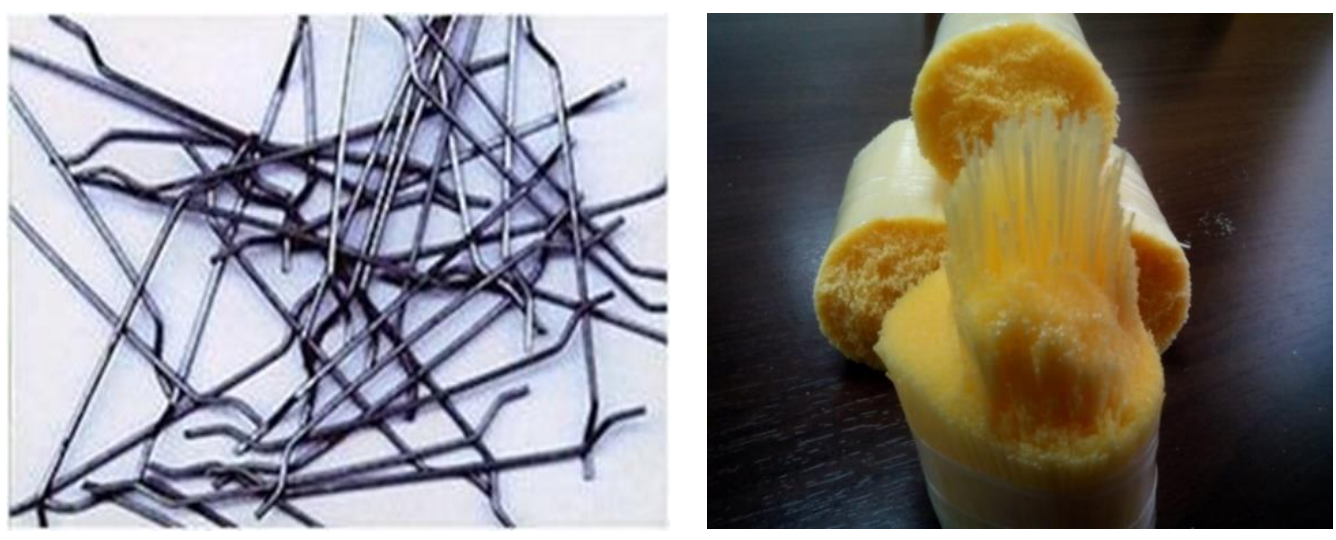

Figure 2. (left) Steel fiber and (right) Synthetic (polypropylene) fiber.

\subsection{Mixing and Proportions}

An electric mixer was used to mix the materials; it contained a flat cylindrical tank where the concrete component can be added. The tank rotated automatically for mixing, and in addition there were three steel blades that hung on the steel cover of the mixer and rotated in the opposite direction of the tank in order to make the mixing more efficient. The total mixing time was from 5.5 to $6 \mathrm{~min}$, partitioned into four stages, and after each stage, 
the ingredients were manually mixed to achieve the highest homogeneity. In the first stage, coarse aggregates, sand, and cement were added and mixed for about $1.5 \mathrm{~min}$.

In the second stage, fibers were added and mixed for $1 \mathrm{~min}$, then in the third stage, the water was added to hold the components together and mixed for about $1.5 \mathrm{~min}$, followed by the superplasticizer, and then mixed for $1.5 \mathrm{~min}$. This procedure was optimized by the authors before starting the experimental program, and it helped to achieve the required workability and homogeneity of the SCC mix [28]. Five mixes were produced: control, which is the plain SCC, and the four mixes with different proportions of steel or polypropylene fibers ( 0.25 and $0.45 \%$ by volume). The fiber content was specified based on the literature and what is used locally; it was 0,2 , and $3.5 \mathrm{~kg} / \mathrm{m}^{3}$ of polypropylene and 0,20 , and $35 \mathrm{~kg} / \mathrm{m}^{3}$ of steel fiber. Mix proportions are presented in Table 3, where the reference mix is based on an optimized SCC with high strength $[29,30]$.

Table 3. Mixtures' composition.

\begin{tabular}{|c|c|c|c|c|c|c|c|}
\hline Mix & Fiber Type & $\begin{array}{c}\text { Fiber } \\
\text { Volume } \\
(\%)\end{array}$ & $\begin{array}{l}\text { Cement } \\
\left(\mathrm{kg} / \mathrm{m}^{3}\right)\end{array}$ & $\begin{array}{c}\text { Fine } \\
\text { Aggregates } \\
\left(\mathrm{kg} / \mathrm{m}^{3}\right)\end{array}$ & $\begin{array}{c}\text { Coarse } \\
\text { Aggregates } \\
\left(\mathrm{kg} / \mathrm{m}^{3}\right)\end{array}$ & $\begin{array}{c}\text { Admixture } \\
\left(\mathrm{kg} / \mathrm{m}^{3}\right)\end{array}$ & $\begin{array}{r}\text { Water } \\
\left(\mathrm{kg} / \mathrm{m}^{3}\right)\end{array}$ \\
\hline Control & - & 0 & 500 & 783 & 939 & 1.5 & 175 \\
\hline S- $-0.25 \%$ & Steel & 0.25 & 500 & 780 & 935 & 1.5 & 175 \\
\hline S- $-0.45 \%$ & Steel & 0.45 & 500 & 778 & 933 & 1.5 & 175 \\
\hline $\mathrm{P}-0.25 \%$ & Polypropene & 0.25 & 500 & 781 & 936 & 1.5 & 175 \\
\hline $\mathrm{P}-0.45 \%$ & Polypropene & 0.45 & 500 & 779 & 934 & 1.5 & 175 \\
\hline
\end{tabular}

\subsection{Testing}

To ensure that the produced mixes have satisfied the European Guidelines for SCC, slump flow diameter and V-tunnel time tests have been conducted directly after mixing. The slump flow diameter test was used to assess the workability and consistency of the concrete. The V-funnel time test was carried out on fresh FRSCC to evaluate the viscosity of the fresh concrete. Both of them were conducted per the European Guidelines for SCC [26]. Specimens were cubes of size $150 \times 150 \times 150 \mathrm{~mm}$ for the compressive strength test, prisms of $70 \times 70 \times 250 \mathrm{~mm}$ for the flexural strength test, and cylinders of $\varnothing 150 \times 300 \mathrm{~mm}$ for the splitting tensile strength and shear strength tests. All specimens were kept in their molds for $24 \mathrm{~h}$ at a temperature of $2{ }^{\circ} \mathrm{C} \pm 1{ }^{\circ} \mathrm{C}$, then they were demolded and immersed in water for 7 days curing. Compressive strength, splitting tensile strength, and three-point flexural strength tests were conducted per European standard [31-33].

The shear strength was tested by the original experimental method: by using a notched cylindrical push-off specimen, which creates two stress-free zones. New boundary conditions were created to transform the compression stress into shear in a limited area. The shape of such a specimen (S-shape) allows for a longitudinal slip, which ensures the occurrence of shear stress in a plane by loading with two forces that equilibrate each other without necessitating the application of supplementary forces on the boundary to ensure equilibrium. The specimen was notched in two symmetrical areas of $1 \mathrm{~cm}$ thickness and $7.5 \mathrm{~cm}$ depth, and the spacing between the notch and base was $10 \mathrm{~cm}$ for both from each side; the used notched cylindrical push-off specimen is shown in Figure 3. After getting the failure load $(\mathrm{P})$ for each test the compressive, splitting tensile, flexural, and shear strengths have been calculated by $\mathrm{MPa}\left(\mathrm{N} / \mathrm{mm}^{2}\right)$ through the equations presented in Table 4 . 


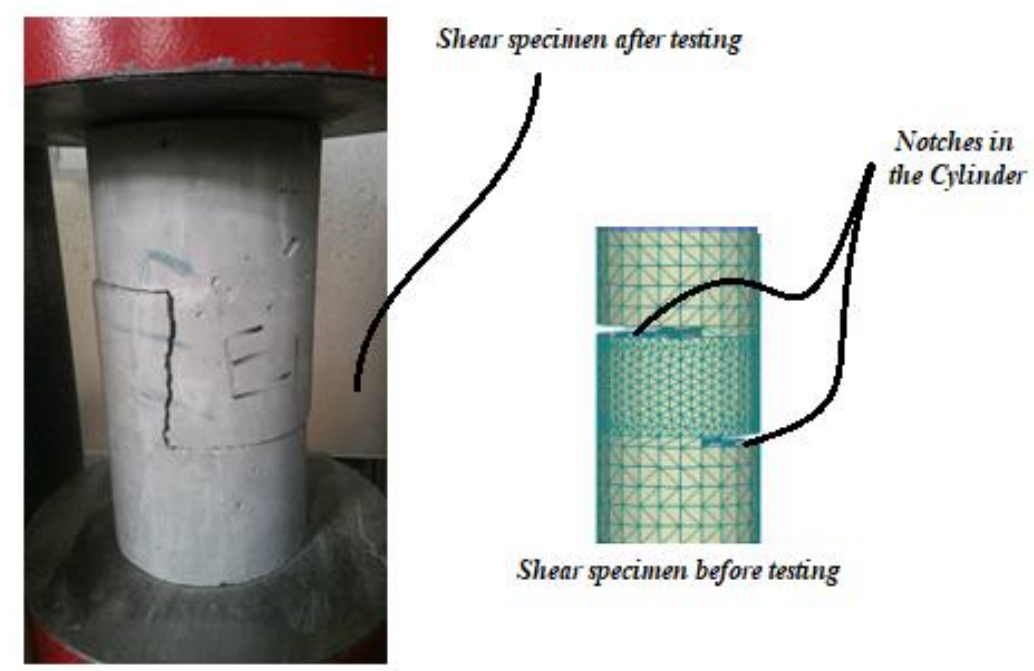

Figure 3. Cylindrical push-off specimen.

Table 4. Formulas for calculating the mechanical strengths.

\begin{tabular}{|c|c|c|}
\hline Test & Formula & Notations \\
\hline $\begin{array}{l}\text { Compressive } \\
\text { strength }\end{array}$ & $\frac{P}{A_{C}}$ & \multirow{4}{*}{$\begin{array}{c}P=\text { load at failure }(\mathrm{KN}) \\
A_{C}=\text { compression area }\left(\mathrm{mm}^{2}\right) \\
L_{T}=\text { length of the cylinder }(\mathrm{mm}) \\
D=\text { diameter of the cylinder }(\mathrm{mm}) \\
b=\text { width of the prism }(\mathrm{mm}) \\
d=\text { depth of the prism }(\mathrm{mm}) \\
L_{F}=\text { length between supports of the } \\
\text { prism }(\mathrm{mm}) \\
A_{S}=\text { shear area }\left(\mathrm{mm}^{2}\right)\end{array}$} \\
\hline $\begin{array}{l}\text { Splitting tensile } \\
\text { strength }\end{array}$ & $\frac{2 P}{\pi D L_{T}}$ & \\
\hline $\begin{array}{l}\text { Flexural } \\
\text { strength }\end{array}$ & $\frac{3 P L_{F}}{2 b d^{2}}$ & \\
\hline $\begin{array}{l}\text { Shear } \\
\text { strength }\end{array}$ & $\frac{P}{A_{S}}$ & \\
\hline
\end{tabular}

By conducting the three points flexural strength test on the prism specimens, they mostly cracked on the bottom side in the middle of the span. Typically, one dominant crack appeared, as is shown in Figure 4 b; however, the control specimens (without the incorporation of fiber) completely split into two halves. These cracked and split specimens were repaired using epoxy resin and tested again; the following repairing procedure was carried out on damaged specimens' postflexural test:

1. The crack was cleaned using compressed air.

2. The epoxy resin was prepared.

3. The crack was filled with the epoxy resin by injecting it using a syringe (Figure 4c).

4. After epoxy injection, the outer edges of the crack were painted using epoxy.

5. The specimen was left for $24 \mathrm{~h}$, then the flexural test was carried out on the repaired specimen (Figure 4d). 


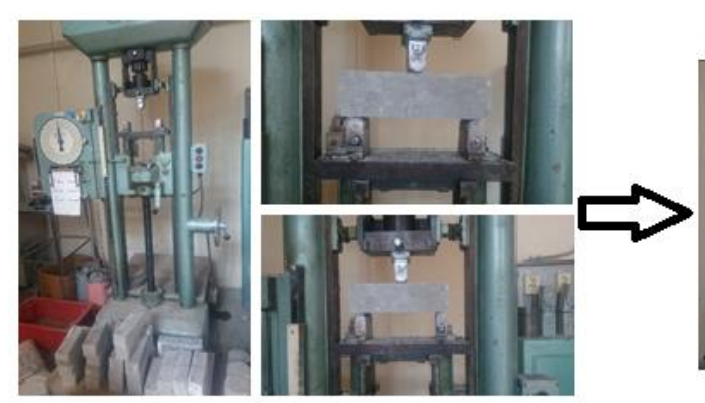

(a) Origin flexural strength test

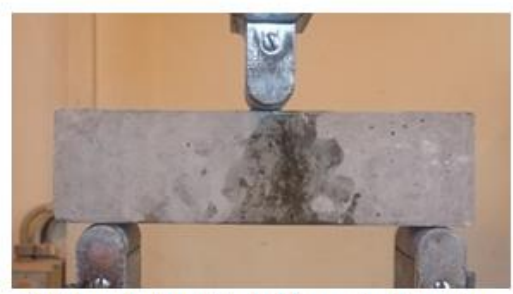

(d) Flexural strength test of the repaired specimen

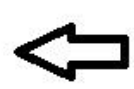

(b) Cracked specimen after testing

(c) Epoxy injection into the cracked specimen
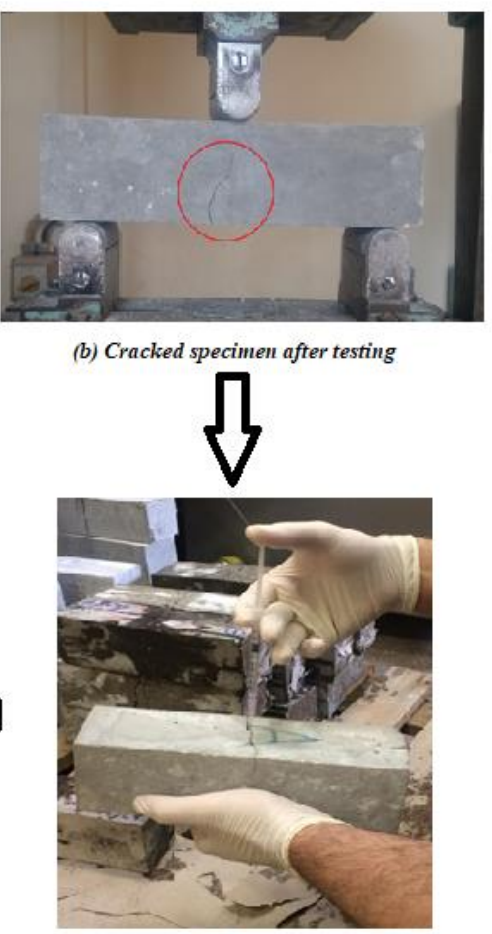

fiber concrete by epoxy injection.

\section{Results}

\subsection{Fresh Properties}

The impact of steel and polypropylene fibers on FRSCC flowability and viscosity (i.e., slump flow and V-funnel time) are shown in Figure 5. Based on the European Guidelines for SCC [26], the obtained results fall within SF2 $(660-750 \mathrm{~mm})$ and VF1 ( $\leq 8 \mathrm{~s})$ classes, reflecting adequate performance at the fresh state. Regardless of fiber type (i.e., steel or polypropylene fibers), the use of fibers led to a gradual decrease in slump flow diameter, reflecting the reduced flowability of FRSCC. For instance, slump flow spread decreased from $73 \mathrm{~cm}$ for the control mix without fibers to 70 and $67 \mathrm{~cm}$ when steel fibers increased from $0.25 \%$ to $0.45 \%$, respectively. Similarly, the corresponding V-funnel times increased from 5.7 to 6.2 and $7.7 \mathrm{sec}$, respectively. This behavior could be attributed to the higher fiber volume that alters the flowability and viscosity of FRSCC mixes due to the increased friction with aggregates [34-36]. The experimental results of Yap et al. [37] reported that adding hybrid steel polypropylene fibers led to the reduced slump flow diameter of assessed FRSCC mixes, reflecting the large surface area of fibers, which necessitate more mortar inside the paste matrix. 
口Slump flow $\quad$ XFlow time

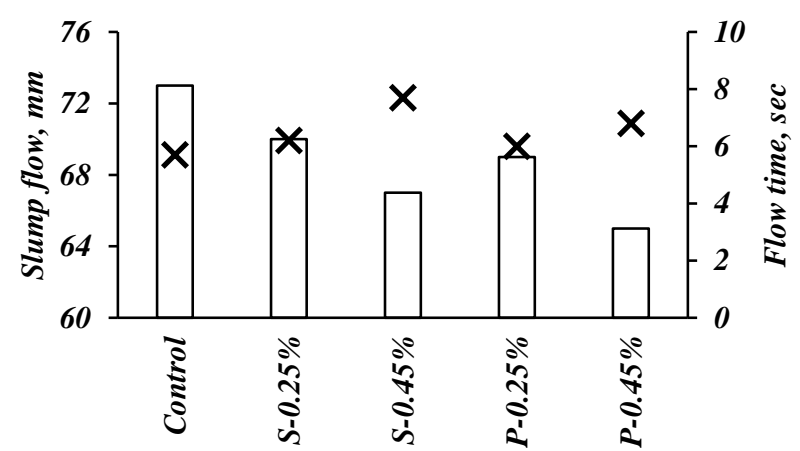

Figure 5. Results of slump flow diameter and V-funnel times.

\subsection{Compressive Strength}

The compressive strength results of FRSCC mixes that include various volume fractions and types of fibers are illustrated in Figure 6. It can be directly noticed that the use of steel or polypropylene fibers in FRSCC does not alter the compressive strength results, since a slight increase in the compressive strength was noted (i.e., the largest increase in compressive strength was $5 \%$ for the FRSCC mix containing $0.25 \%$ of polypropylene fiber fraction) [38]. Similarly, there was a marginal increase in the compressive strength for the steel fibers mixtures with 0.25 and $0.45 \%$ fiber volume fractions in comparison to the control mix. Several studies reported the positive effect of polypropylene fibers on the compressive strength of concrete $[13,39,40]$. The data reported in the aforementioned studies agree with the current experimental results, implying that polypropylene fibers have limited effects on concrete compressive strength [11,41]. This enhancement may be attributed to the effect of fibers on reducing the formation and development of cracks under axial load. It is worth mentioning that the reduction of compressive strength developed by increasing the volume fraction of fibers (i.e., polypropylene fibers) can be related to the fact that increasing the volume of fibers can alter the workability of FRSCC mixes. Consequently, poorly compacted zones are formed inside the concrete, which affects the development of concrete compressive strength [42].

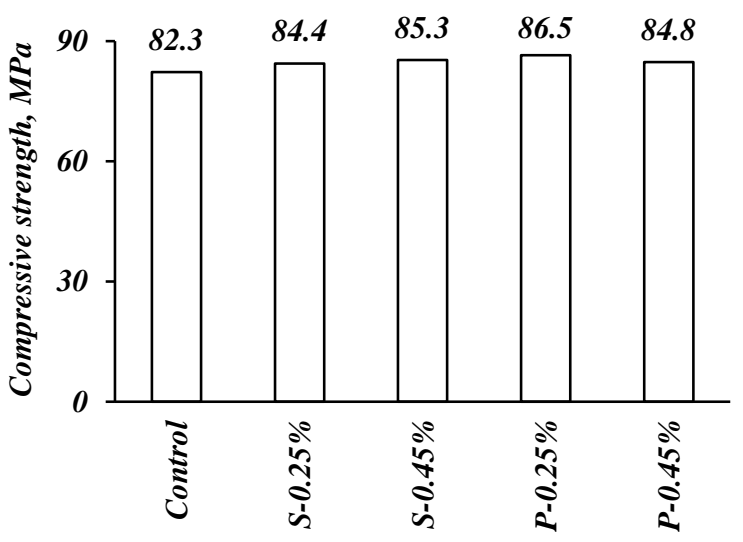

Figure 6. Effect of fibers on the compressive strength.

\subsection{Splitting Tensile Strength}

To assess the impact of fibers on the tensile strength of casted FRSCC, splitting tensile strength tests were carried out on specimens, and the corresponding results are plotted in Figure 7. As expected, the addition of fibers had a significant impact on the splitting tensile strength of mixes. The positive effect of the addition of fibers is noticeable. In comparison with the control mix, the improvement in splitting tensile strength when fibers were added was in the range of $25-46 \%$. The S- $0.45 \%$ mix incorporating $0.45 \%$ by volume of steel 
fibers showed the highest enhancement in splitting tensile strength. Similarly, the mixes with polypropylene fibers showed enhanced performance in the splitting tensile strength, reaching up to $34 \%$ for the mix incorporating $0.45 \%$ by volume of fibers. This could be explained by the fact that fibers bridge cracks during loading, limiting their growth and propagation, thus leading to increased ultimate splitting tensile stress [9]. Results are in agreement with Yap et al. [37] and Sadrinejad et al. [43], highlighting the positive impact of polypropylene fibers in enhancing splitting tensile strength. Also, it is worth mentioning that splitting tensile strength was more vulnerable than the compressive strength results when fibers were incorporated in the FRSCC mixes at the same fiber content.

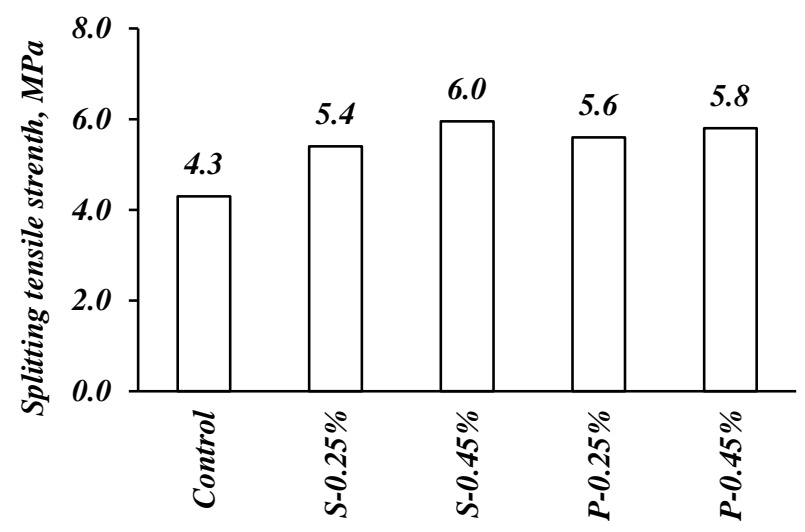

Figure 7. Effect of fibers on the splitting tensile strength.

\subsection{Shear Strength}

According to Figure 8, the increment of shear strength is affected by fiber type and content. The use of $0.45 \%$ by volume of steel fibers in the FRSCC mix increased the shear strength by about $16 \%$ compared to that of the control mix, while using polypropylene instead of steel fibers led to a $9 \%$ increase in the shear strength. This could be related to the higher crack-arresting capacity of bridging in steel fiber with rough surfaces compared to the smooth surfaces of polypropylene fibers. The rough surface of steel fibers provides higher shear strength at the matrix/fiber interface compared to the smooth surfaces of polypropylene fibers [44]. Additionally, the use of steel fibers has proven its efficiency in enhancing the shear capacity and ductility of reinforced concrete by increasing the residual strength of concrete at the postcracking stage; fibers provide bridging stresses through the cracks so the stress is transferred across the cracked section $[45,46]$.

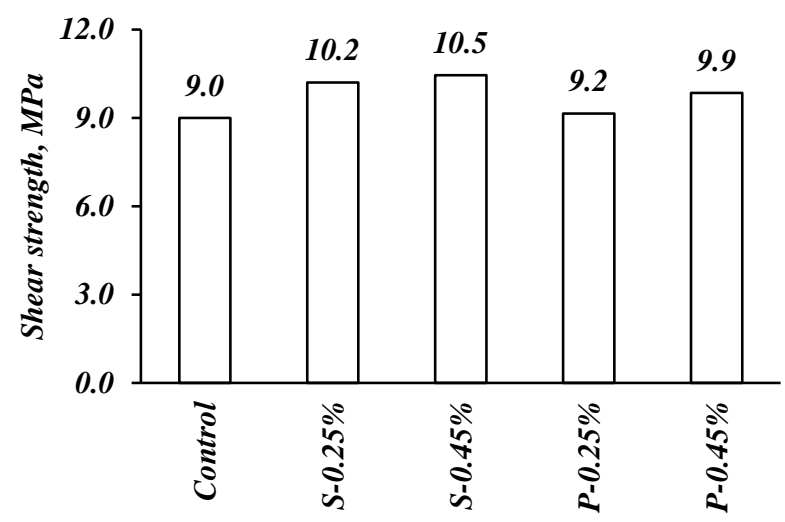

Figure 8. Effect of fibers on the shear strength.

\subsection{Flexural Strength (Before and After Epoxy)}

The flexural strength test results which show the effect of using steel and polypropylene fibers with and without epoxy injection are plotted in Figure 9. Regardless of the 
type and volume fraction of fibers, the addition of fibers in FRSCC mixes enhanced the flexural strength performance. Different results were reported in the literature on the effect of fibers on the flexural strength of cementitious mixtures. For the given fiber content, flexural strength was expected to increase. In comparison with the control mix, the improvement in flexural strength when fibers were added was in the range of $6-21 \%$. The best performance in flexural strength corresponded to the S- $0.45 \%$ mix with steel fibers. The results of the polypropylene fibers concrete point to the superior efficiency of steel fibers over polypropylene fibers, since polypropylene fibers have lower tensile strength and elastic modulus than those of steel fibers. The general improvement in the flexural strength capacity of FRSCC mixes with fibers can be attributed to the fiber capacity to limit crack propagation, which directly decreases the generation of new cracks [44]. The results of this paper agreed with Šušteršič et al. [47], who found steel fiber is so effective that it not only increases the bearing capacity of concrete after repairing the cracks with epoxy, but also enhances the concrete behavior after the first crack improves.

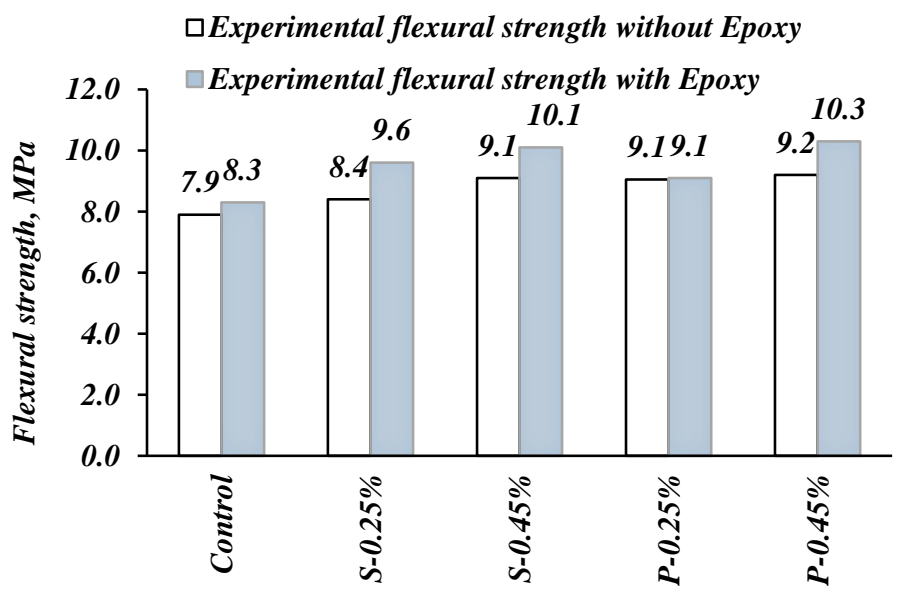

Figure 9. Effect of fibers on the flexural strength.

Based on experimental observations, all tested specimens failed within the middle third section. After breakage, beams repaired with epoxy injection performed differently. Most of the repaired control specimens that split at new different places had higher flexural strength values compared to the specimens that split at the same places (see Figure 10). In comparison with the control mix, the improvement in flexural strength when fibers were introduced was in the range of $9-24 \%$. The best performance in flexural strength corresponded to the S- $0.45 \%$ mix with steel fibers, reaching an ultimate value of $10.3 \mathrm{MPa}$. The injected epoxy is characterized by having a higher tensile strength and better strain than concrete. Therefore, as can be observed from Figure 10, the failure of concrete specimens in flexure did not occur in the region where the epoxy has been injected. The epoxy injection method provided an increase in stiffness of the tested element.

The correlation between the flexural strength of the FRSCC before and after repairing by epoxy is presented in Figure 11; the correlation is linear and with a coefficient of determination of $80 \%$. It could be concluded that repairing FRSCC is not only an economical or sustainable choice, but also a valuable one for enhancing the concrete properties. Through the presented correlation, the flexural strength of FRSCC after repairing with epoxy can be predicted. It is important to mention that this behavior was observed for the FRSCC with high strength, where its compression strength at 28 days exceeded $82 \mathrm{MPa}$ for all mixtures. 

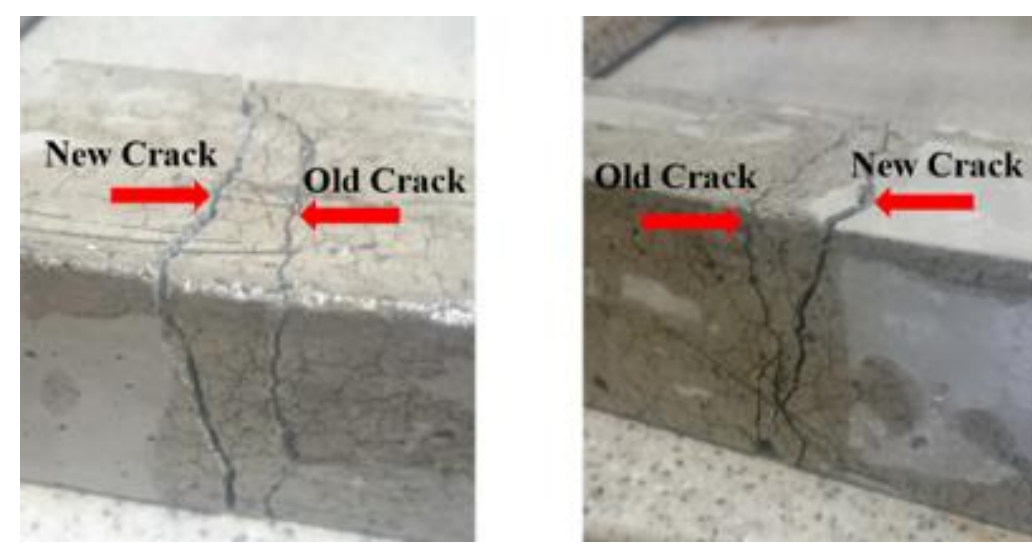

Figure 10. New and old cracks in the repaired reference specimens.

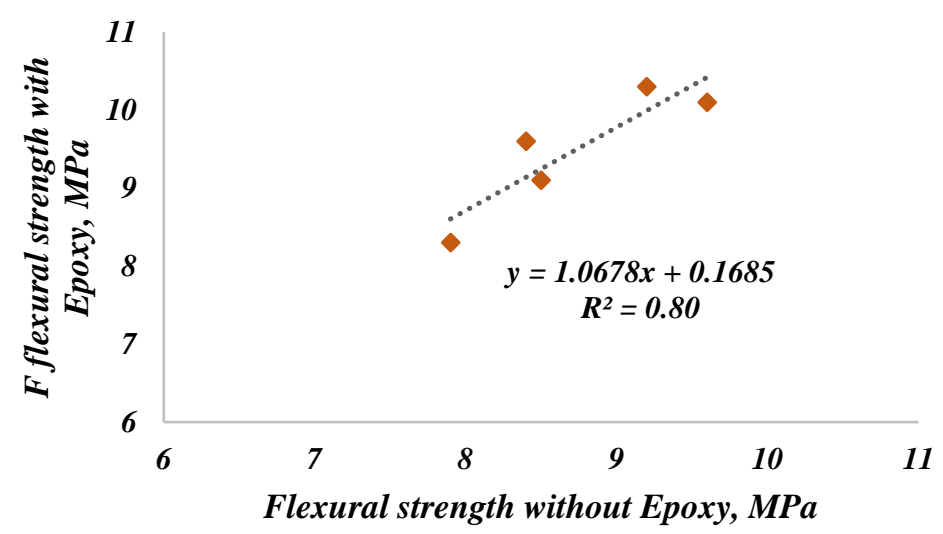

Figure 11. Correlation between the flexural strength of FRSCC before and after repairing with Epoxy.

It has been recognized by Feng et al. [48] that the polypropylene fiber encompassed by C-S-H gel ruptured due to the low tensile strength, while steel fiber had a smooth surface that detached from its surrounding matrix. The few hydration products on the steel fiber surface imply the relatively weaker interfacial bond between steel fiber and matrix. As an attempt to explain the behavior of FRSCC after being repaired with epoxy, scanning electron microscope (SEM) images were produced to investigate the microstructure behavior of fiber-reinforced concrete, as shown in Figure 12. It can be seen that the transition zone between the fiber itself and concrete has high porosity, and one reason for the increasing flexural strength after repairing by epoxy could be this porosity. The injection of epoxy into a concrete crack introduces the epoxy resin to the pore zone between the concrete and fiber. Thus, fiber sticks to the concrete, and flexural strength is increased. Once the main crack zone becomes much stronger, the new crack may appear in a new place at the second trial of testing (testing after epoxy injection), and then a new weakest point appears. Polypropylene fibers tend to increase permeability, but to a much lesser extent compared to steel fiber. However, for the reference mix, the increase in flexural strength was slight, and this may be because the high accurate manual repairing of the beam, which was split completely, helped in that slight improvement of strength. 

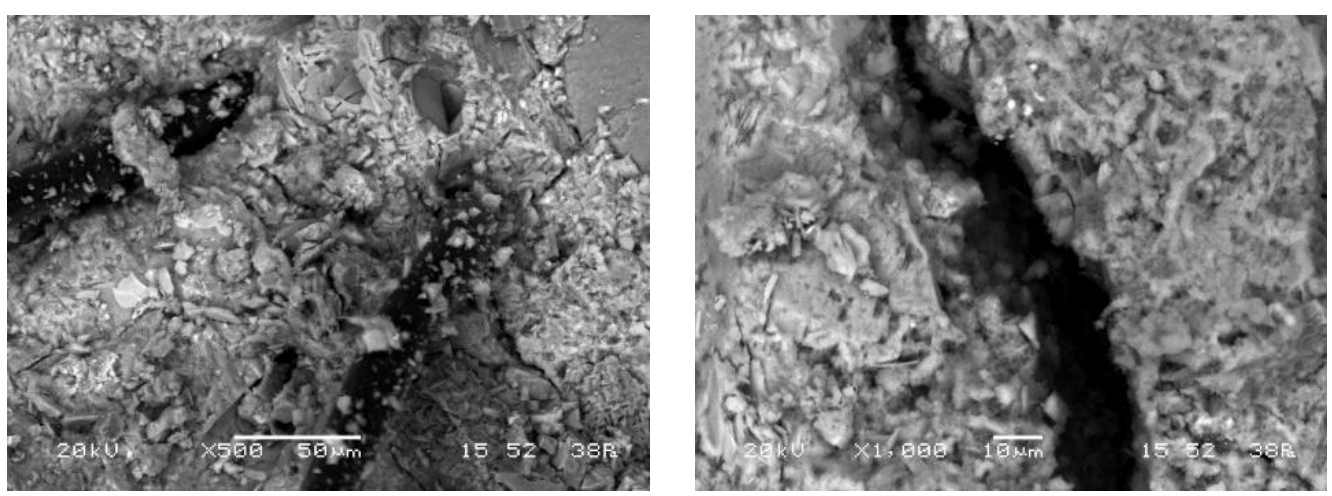

Figure 12. Microstructure SEM images of fiber reinforced concrete.

The results of the compressive and flexural strengths of FRSCC test results are correlated in Figure 13. The flexural strength of concrete can be predicted from compressive strength results using the empirical relations of suggested standards: ACI 363 [49], CEBfib [50], and AS 3600 [51]. Among all the relations used to predict the flexural strength of concrete, ACI 363 [49] showed the closest values to the experimental results. It is worth mentioning that ACI 363 [49] is intended to be used for high-strength concrete, which is the case for the mixes used in this study. The correlation between compressive and flexural strengths is considered to be adequate $\left(R^{2}=0.70\right)$. Since the results of flexural strength before using the epoxy meet the predicted values proposed in the aforementioned standards, the flexural strength results after using the epoxy will do, considering the compressive strength is the same.

$$
\begin{gathered}
f_{r}=0.94 \sqrt{f_{c}} \\
f_{r}=0.46\left(f_{c}\right)^{2 / 3} \\
f_{r}=0.6 \sqrt{f_{c}}
\end{gathered}
$$

where, $f_{r}=$ flexural strength $(\mathrm{MPa}), f_{c}=$ cylindrical compressive strength $(\mathrm{MPa})$.

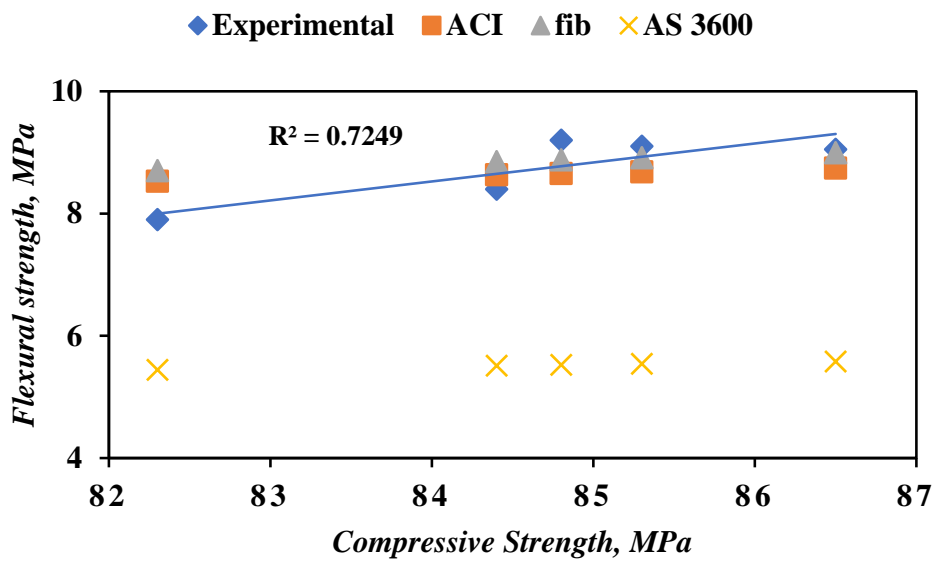

Figure 13. Relationship between flexural strength and compressive strength of FRSCC.

\section{Conclusions}

This paper is a part of a comprehensive research project undertaken to evaluate the effects of the addition of steel and polypropylene fibers on the fresh and mechanical properties of FRSCC proportioned with high strength.

The research also conducted the epoxy injection technique to strengthen the FRSCC after cracking. It was carried out on ruptured concrete specimens to assess the efficiency of the epoxy resin adhesive injection retrofitting technique for strength and stiffness. The 
simultaneous application of epoxy injection in FRSCC for repairing damaged concrete beams was shown to be highly effective.

According to the experimental results, the incorporation of steel or polypropylene fibers led to reduced responses in the workability of FRSCC. Such phenomena become aggravated when mixtures are proportioned with higher contents of fibers.

The impact of polypropylene or steel fibers on the compressive strength results was marginal. The positive impact of fibers on splitting tensile strength was noticeable, given that the fiber bridging action that limits crack propagation.

Steel fibers with high tensile properties could significantly improve the flexural strength and shear capacity of FRSCC, owing to the effect of fibers on the postcracking response and shear stress transfer across the cracks. Repairing FRSCC with epoxy enhances its flexural strength, unlike the normal concrete produced without fiber. The porous transition zone between the fiber and cement matrix helps to improve the strength after repair, as presented by the SEM images. Finally, the experimental results of flexural strengths were found to be predictable by several standards.

Author Contributions: Conceptualization, M.A.A.; methodology, M.A.A., A.N. and A.E.; validation, M.A.A. and J.F.; formal analysis, A.N.; investigation, A.E.; resources, A.N. and A.E.; writingoriginal draft preparation, M.A.A.; writing—review and editing, J.F.; supervision, M.A.A.; project administration, M.A.A.; funding acquisition, J.F. All authors have read and agreed to the published version of the manuscript.

Funding: The authors wish to thank the Czech Science Foundation which support the research under project No. 19-14789S.

Institutional Review Board Statement: Not applicable.

Informed Consent Statement: Not applicable.

Data Availability Statement: Not applicable.

Acknowledgments: The authors greatly appreciate the support of Rita Nemes at Budapest University of Technology and Economics and Abdulkader El-Mir at University of Balamand.

Conflicts of Interest: The authors declare no conflict of interest.

\section{References}

1. Liao, W.-C.; Perceka, W.; Liu, E.-J. Compressive Stress-Strain Relationship of High Strength Steel Fiber Reinforced Concrete. J. Adv. Concr. Technol. 2015, 13, 379-392. [CrossRef]

2. Amin, M.; Tayeh, B.A.; Saad Agwa, I. Investigating the mechanical and microstructure properties of fibre-reinforced lightweight concrete under elevated temperatures. Case Stud. Constr. Mater. 2020, 13, e00459. [CrossRef]

3. Matar, P.; Assaad, J.J. Concurrent effects of recycled aggregates and polypropylene fibers on workability and key strength properties of self-consolidating concrete. Constr. Build. Mater. 2019, 199, 492-500. [CrossRef]

4. da Silva, G.C.S.; Christ, R.; Pacheco, F.; de Souza, C.F.N.; Gil, A.M.; Tutikian, B.F. Evaluating steel fiber-reinforced self-consolidating concrete performance. Struct. Concr. 2020, 21, 448-457. [CrossRef]

5. Thomas, J.; Ramaswamy, A. Mechanical properties of steel fiber-reinforced Concrete. Mater. Civ. Eng. 2007, 19, 385-392. [CrossRef]

6. American Concrete Institute. An ACI Standard and Report. Building Code Requirements for Structural Concrete (ACI 318-14). Commentary on Building Code Requirements for Structural Concrete (ACI 318R-14); American Concrete Institute: Farmington Hills, MI, USA, 2014; Available online: https:/ / www.concrete.org/store/productdetail.aspx?ItemID=318U14\&Language=English (accessed on 1 September 2021).

7. Fédération Internationale du Béton. Model Code for Concrete Structures 2010; Fédération Internationale du Béton: Lausanne, Switzerland, 2010.

8. Khaloo, A.; Raisi, E.M.; Hosseini, P.; Tahsiri, H. Mechanical performance of self-compacting concrete reinforced with steel fibers. Constr. Build. Mater. 2014, 51, 179-186. [CrossRef]

9. Dawood, E.T.; Ramli, M. Mechanical properties of high strength flowing concrete with hybrid fibers. Constr. Build. Mater. 2012, 28, 193-200. [CrossRef]

10. Marcos-Meson, V.; Michel, A.; Solgaard, A.; Fischer, G.; Edvardsen, C.; Skovhus, T.L. Corrosion resistance of steel fibre reinforced concrete-A literature review. Cem. Concr. Res. 2018, 103, 1-20. [CrossRef]

11. Bolat, H.; Simşek, O.; Çullu, M.; Durmuş, G.; Can, Ö. The effects of macro synthetic fiber reinforcement use on physical and mechanical properties of concrete. Compos. Part B Eng. 2014, 61, 191-198. [CrossRef] 
12. Kakooei, S.; Akil, H.M.; Jamshidi, M.; Rouhi, J. The effects of polypropylene fibers on the properties of reinforced concrete structures. Constr. Build. Mater. 2012, 27, 73-77. [CrossRef]

13. Han, B.; Sun, S.; Ding, S.; Zhang, L.; Yu, X.; Ou, J. Review of nanocarbon-engineered multifunctional cementitious composites. Compos. Part A Appl. Sci. Manuf. 2015, 70, 69-81. [CrossRef]

14. Sun, Z.; Xu, Q. Microscopic, physical and mechanical analysis of polypropylene fiber reinforced concrete. Mater. Sci. Eng. A 2019, 527, 198-204. [CrossRef]

15. Afroughsabet, V.; Ozbakkaloglu, T. Mechanical and durability properties of high-strength concrete containing steel and polypropylene fibers. Constr. Build. Mater. 2015, 94, 73-82. [CrossRef]

16. Khayat, K.H.; Roussel, Y. Testing and performance of fiber-reinforced, self-consolidating concrete. Mater. Struct. 2000, 33, 391-397. [CrossRef]

17. Khayat, K.H.; Kassimi, F.; Ghoddousi, P. Mixture design and testing of fiber-reinforced self-consolidating concrete. ACI Mater. J. 2014, 111, 143-152. [CrossRef]

18. American Concrete Institute. ACI Committee 54. Concrete Repair Guide (ACI 546R-04); American Concrete Institute: Farmington Hills, MI, USA, 2004; Available online: https:/ / www.concrete.org/publications/internationalconcreteabstractsportal/m/details/ id/13543 (accessed on 1 September 2021).

19. Issa, C.A.; Debs, P. Experimental study of epoxy repairing of cracks in concrete. Constr. Build. Mater. 2007, 21, 157-163. [CrossRef]

20. Ekenel, M.; Myers, J.J. Durability performance of RC beams strengthened with epoxy injection and CFRP fabrics. Constr. Build. Mater. 2007, 21, 1182-1190. [CrossRef]

21. French, C.W.; Thorp, G.A.; Tsai, W.J. Epoxy repair techniques for moderate earthquake damage. ACI Struc. J. 1990, 87, 416-424.

22. Nikopour, H.; Nehdi, M. Shear repair of RC beams using epoxy injection and hybrid external FRP. Mater. Struct. Constr. 2011, 44, 1865-1877. [CrossRef]

23. Ahmad, S.; Elahi, A.; Barbhuiya, S.; Farooqi, Y. Repair of cracks in simply supported beams using epoxy injection technique. Mater. Struct. Constr. 2013, 46, 1547-1559. [CrossRef]

24. Kim, T.K.; Park, J.S. Performance Evaluation of Concrete Structures Using Crack Repair Methods. Sustainability 2021, $13,3217$. [CrossRef]

25. European Committee for Standardization. ISO 196-2:2013. Cement Testing Methods. Part 2: Chemical Analysis of Cement; European Committee for Standardization: Brussels, Belgium, 2013.

26. The European Federation of Specialist Construction Chemicals and Concrete Systems (EFNARC). The European Guidelines for Self-Compacting Concrete. Specification, Production and Use. 2005. Available online: https://wwwp.feb.unesp.br/pbastos/c especiais / Efnarc.pdf (accessed on 1 September 2021).

27. Hambach, M.; Volkmer, D. Properties of 3D-printed fiber-reinforced Portland cement paste. Cem. Concr. Compos. 2017, 79, 62-70. [CrossRef]

28. Liu, G.M.; Cheng, W.M.; Chen, L.J.; Pan, G.; Liu, Z.X. Rheological properties of fresh concrete and its application on shotcrete. Constr. Build. Mater. 2020, 243, 118180. [CrossRef]

29. Abed, M. Self-compacting high-performance concrete in terms of mixing proportions and procedure. Concr. Struct. 2018, 19, 22-27. [CrossRef]

30. Abed, M.A. Green Self-Compacting High-Performance Concrete. Ph.D. Thesis, Budapest University of Technology and Economics, Budapest, Hungary, 2019. Available online: https:/ / repozitorium.omikk.bme.hu/handle/10890/13162 (accessed on 1 September 2021).

31. British Standards Institution. BSI EN 12390-3 (2009). Testing Hardened Concrete. Part 3: Compressive Strength of Test Specimens; British Standards Institution: London, UK, 2009.

32. British Standards Institution. BSI EN 12390-5 (2009). Testing Hardened Concrete. Part 5: Flexural Strength of Test Specimens; British Standards Institution: London, UK, 2009.

33. British Standards Institution. BSI EN 12697-23 (2004) Bituminous Mixtures. Test Methods for Hot Mix Asphalt. Part 23: Determination of the Indirect Tensile Strength of Bituminous Specimens; British Standards Institution: London, UK, 2004.

34. Mastali, M.; Dalvand, A. Fresh and hardened properties of self-compacting concrete reinforced with hybrid recycled steelpolypropylene fiber. J. Mater. Civ. Eng. 2017, 29, 1-15. [CrossRef]

35. Mehdipour, I.; Vahdani, M.; Libre, N.A.; Shekarchi, M. Relationship between workability and mechanical properties of fibrereinforced self-consolidating mortar. Mag. Concr. Res. 2013, 65, 1011-1022. [CrossRef]

36. Dhonde, H.B.; Mo, Y.L.; Hsu, T.C.; Vogel, J. Fresh and hardened properties of self-consolidating fiber-reinforced concrete. ACI Mater. J. 2007, 5, 491-500.

37. Yap, S.P.; Alengaram, U.J.; Jumaat, M.Z. Enhancement of mechanical properties in polypropylene- and nylon-fibre reinforced oil palm shell concrete. Mater. Des. 2013, 49, 1034-1041. [CrossRef]

38. Lee, J.H.; Cho, B.; Choi, E. Flexural capacity of fiber reinforced concrete with a consideration of concrete strength and fiber content. Constr. Build. Mater. 2017, 138, 222-231. [CrossRef]

39. Nili, M.; Afroughsabet, V. The long-term compressive strength and durability properties of silica fume fiber-reinforced concrete. Mater. Sci. Eng. A 2012, 531, 107-111. [CrossRef]

40. Song, P.S.; Hwang, S.; Sheu, B.C. Strength properties of nylon- and polypropylene-fiber-reinforced concretes. Cem. Concr. Res. 2005, 35, 1546-1550. [CrossRef] 
41. Alberti, M.G.; Enfedaque, A.; Gálvez, J.C. On the mechanical properties and fracture behavior of polyolefin fiber-reinforced self-compacting concrete. Constr. Build. Mater. 2014, 55, 274-288. [CrossRef]

42. Mydin, A.O.; Soleimanzadeh, S. Effect of polypropylene fiber content on flexural strength of lightweight foamed concrete at ambient and elevated temperatures. Adv. Appl. Sci. Res. 2012, 3, 2837-2846.

43. Sadrinejad, I.; Madandoust, R.; Ranjbar, M.M. The mechanical and durability properties of concrete containing hybrid synthetic fibers. Constr. Build. Mater. 2018, 178, 72-82. [CrossRef]

44. Mastali, M.; Dalvand, A.; Sattarifard, A.R. The impact resistance and mechanical properties of reinforced self-compacting concrete with recycled glass fibre reinforced polymers. J. Clean. Prod. 2016, 124, 312-324. [CrossRef]

45. Gali, S.; Subramaniam, K.V.L. Improvements in fracture behavior and shear capacity of fiber reinforced normal and self consolidating concrete: A comparative study. Constr. Build. Mater. 2018, 189, 205-217. [CrossRef]

46. Yoo, D.-Y.; Yoon, Y.-S.; Banthia, N. Flexural response of steel-fiber-reinforced concrete beams: Effects of strength, fiber content, and strain-rate. Cem. Concr. Compos. 2015, 64, 84-92. [CrossRef]

47. Šušteršič, J.; Zajc, J.; Jure, K.; Korla, J.; Leskovar, I. Efficient Repair of Crack in SFRC with Low-Viscosity Epoxy Adhesive. Adv. Mater. Res. 2015, 1129, 453-459. [CrossRef]

48. Feng, J.; Gao, X.; Li, J.; Dong, H.; Hec, Q.; Liang, J.; Sun, W. Penetration resistance of hybrid-fiber-reinforced high-strength concrete under projectile multi-impact. Const. Build. Mater. 2019, 202, 341-352. [CrossRef]

49. American Concrete Institute. ACI 363R-92 State of the Art Report on High Strength Concrete; American Concrete Institute: Farmington Hills, MI, USA, 1992; Available online: https://www.concrete.org/publications/internationalconcreteabstractsportal/m/details/ $\mathrm{id} / 5194$ (accessed on 1 September 2021).

50. Comité Euro-International du Béton. CEB-FIP Model Code 1990: Design Code; Thomas Telford Ltd.: London, UK, 1990.

51. Standards Association of Australia. Australian Standard for Concrete Structures; Standards Association of Australia: Sydney, Australia, 2001; Available online: https:/ / www.icevirtuallibrary.com/doi/book/10.1680/ceb-fipmc1990.35430 (accessed on 1 September 2021). 